\title{
A contribution to ants (Hymenoptera: Formicidae) from North and Northwestern regions of Iran
}

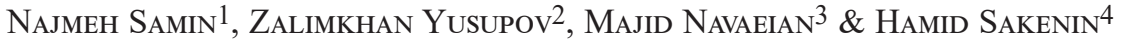

\author{
${ }^{1}$ Young Researchers and Elite Club, Science and Research Branch, Islamic Azad University, \\ Tehran, Iran; email: n_samin63@yahoo.com \\ ${ }^{2}$ Tembotov Institute of Ecology of Mountain Territories of Russian Academy of Science, \\ Nalchik, Russia \\ ${ }^{3}$ Department of Biology, Yadegar- e- Imam Khomeini (RAH) Shahre Rey Branch, Islamic Azad University, \\ Tehran, Iran \\ ${ }^{4}$ Department of Plant Protection, Qaemshahr Branch, Islamic Azad University, \\ Mazandaran, Iran
}

\begin{abstract}
Samin, N., Yusupov, Z., Navaeian, M. \& Sakenin, H.: A contribution to ants (Hymenoptera: Formicidae) from North and Northwestern regions of Iran.

Abstract: This paper deals with faunistic data on the Formicidae (Hymenoptera) from north and northwestern Iran. Totally 15 species in 10 genera were collected and identified, which four species are new records for the fauna of Iran. Four species are new records for the fauna of Iran: Myrmica ruginodis Nylander, 1846, Strongylognathus rehbinderi Forel, 1904, Temnothorax interruptus (Schenck, 1852), and Tetramorium immigrans Santschi, 1927.
\end{abstract}

Keywords: Ant, Formicidae, fauna, new records, Iran

\section{Introduction}

The family Formicidae (Hymenoptera: Vespoidea) includes more than 13.700 species worldwide in 337 genera and 17 extant subfamilies (Bolton 2020). The first fossil records of ants are known from the Cretaceous (ca 100 millions years ago). Their radiance however is dated much earlier (MOREAU et al. 2006). Ants are distributed mainly in the tropical and subtropical regions, where species richness and abundance of this family may be overwhelming (HöLLDOBLER \& Wilson 1990, AgOsTI et al. 2000). All ants are eusocial insects, which live in societies with overlapping adult generations. The colonies of all ants in temperate zone are perennial, lasting over more years (HöLLDOBLER \& WILSON 1990). They belong among principal predators of arthropods (WILSON 2000) and play a significant role as herbivores (CHERRETT 1986). They have a profound influence in soil turnover and soil properties (GRIMALDI \& ENGEL 2005, WERNER \& WIEZIK 2007).

The earliest information on the fauna of Iranian ants is given in the work of FARAHBAKHSH (1961), where he indicates four species: Camponotus ligniperda (Latreille, 1802), Crematogaster scutellaris (Olivier, 1791), Tapinoma karavaievi Emery, 1925 and Cataglyphus sp. Modarres Awal (1997 and 2012) listed 16 species in 9 genera, and 56 species in 17 genera, respectively. PAKNIA et al. (2008) listed 110 species in 26 genera 
and six subfamilies (Aenictinae, Dolichoderinae, Dorylinae, Formicinae, Myrmicinae, and Ponerinae) as the fauna of Iran. Several dozen works have been published (TIRGARI \& Paknia 2004, Paknia 2006, PAKnia \& Kami 2007, Ghahari et al. 2009, Rafinejad et al. 2009, PaKnia 2010, Paknia et al. 2010, Radchenko \& Paknia 2010, Firouzi et al. 2011, Ghahari et al. 2011, Mohammadi et al. 2012, Hossein NeZHaD et al. 2012, Kiran et al. 2013, SHIRAN et al. 2013, GHAHARI et al. 2015, Hosseini et al. 2015, KHANDEHroo et al. 2015, Mirzamohamadi et al. 2015, Moradloo et al. 2015, Mortazavi et al. 2015, Ghobadi et al. 2016, Heidari et al. 2017, Pashaei Rad et al. 2018, Borowiec et al. 2019, Khalili-Moghadam et al. 2019, Mohseni Rad et al. 2019, Salata et al. 2020), and currently, more than 200 species of ants have been reported from Iran. The aim of this paper is a faunistic study on Formicidae from North and Northwestern regions of Iran, and introducing of four species as new records for the Iranian fauna.

\section{Material and methods}

Ant sampling by hand collecting was done in the spring and summer in some regions of north and northwestern Iran. The specimens were preserved in 95\% alcohol and taken to the laboratory for sorting and identification. Some of the specimens were confirmed by the late C.A. Collingwood (North Yorkshire, UK). The provinces of Iran are represented in figure 1. Photos are given for new country records (Figs. 2, 3).

\section{Results}

In total, 15 species of Formicidae (Hymenoptera) within 10 genera were collected and identified from different regions of nort and northwestern Iran. The list of species is given below alphabetically.

Aphaenogaster muschtaidica Emery, 1908 - Ardabil province, Germi, 5 w., 24. vi.2009.

Distribution in Palaearctic: Caucasus.

Camponotus (Myrmentoma) atricolor (Nylander, 1849) - West Azarbayjan province, Ourmieh (Seroo Road), 4 w., 16.viii.2013.

Distribution in Palaearctic: Austria, Azerbaijan, Bulgaria, Greece, Hungary, Romania, Russian Federation.

Camponotus (Myrmentoma) aegaeus Emery, 1915 - East Azarbayjan province, Khodafarin, 7 w., ix.2011.

Distribution in Palaearctic: Crete, Dodecanese Islands, Turkey.

Camponotus (Myrmentoma) candiotes Emery, 1894 - West Azarbayjan province, Oshnavieh, 6 w., 9.vii.2013.

Distribution in Palaearctic: Greece, Crete, Dodecanese Islands, Turkey.

Camponotus (Myrmentoma) kiesenwetteri (Roger, 1859) - East Azarbayjan province, Jolfa, 9 w., 28.v.2014.

Distribution in Palaearctic: Greece, Crete, Cyclades Islands, Cyprus, Dodecanese Islands, Turkey. 


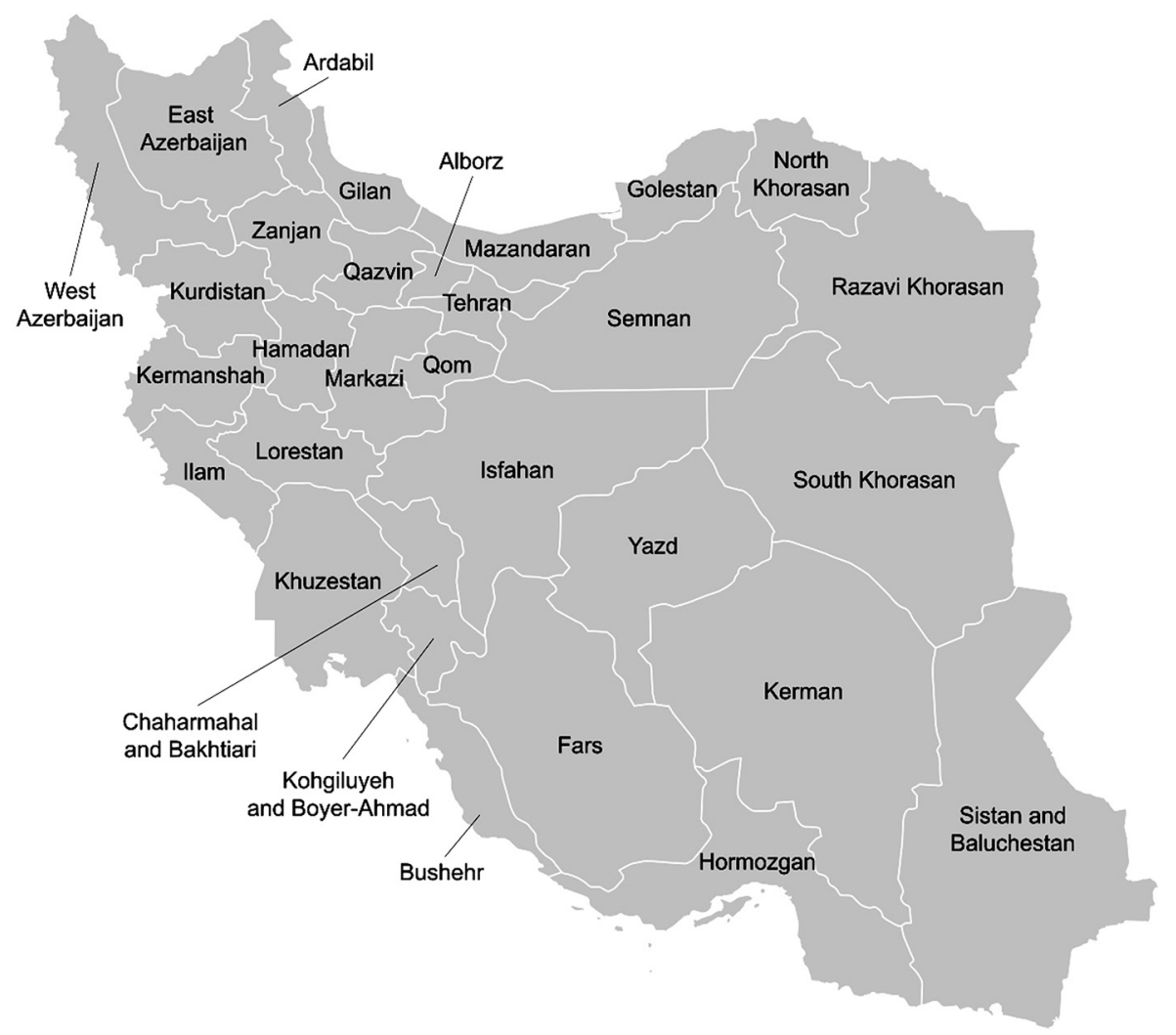

Fig. 1- Map of Iran with boundaries of provinces

Camponotus (Tanaemyrmex) ionius Emery, 1920 - Guilan province, Talesh, 5 w., 2 m., 2.ix.2012.

Distribution in Palaearctic: Bulgaria, Cyclades Islands, Dodecanese Islands, Greece, North Aegean Islands, Turkey, former Yugoslavia.

Colobopsis truncata (Spinola, 1808) - West Azarbayjan province, Maku, 8 w., 25. vii.2011.

Distribution in Palaearctic: Mostly southern and central Europe, also northwest Africa, Crimea, Caucasus, Eastern Mediterranean, and the Middle East.

Lasius myops Forel, 1894 - West Azarbayjan province, Maku, 6 w., 1 m., 25. vii.2011.

Distribution in Palaearctic: Azerbaijan, Belgium, Bulgaria, Czech Republic, Greece, Italy, Spain, Switzerland.

Lepisiota caucasica (Santschi, 1917) - Guilan province, Talesh, 8 w., 2.ix.2012.

Distribution in Palaearctic: Caucasus. 
Myrmica ruginodis Nylander, 1846 - Ardabil province, Aslanduz, 6 w., 10.ix.2010. New record for Iran.

Distribution in Palaearctic: Albania, Andorra, Armenia, Austria, Belarus, Belgium, Bulgaria, Channel Islands, China, Croatia, Czech Republic, Democratic Peoples Republic of Korea, Denmark, Estonia, Finland, Georgia, Germany, Greece, Hungary, Iberian Peninsula, Latvia, Lithuania, Luxembourg, Mongolia, Netherlands, Norway, Poland, Portugal, Republic of Korea, Republic of Macedonia, Romania, Russian Federation, Slovakia, Slovenia, Spain, Sweden, Switzerland, United Kingdom of Great Britain and Northern Ireland.

Myrmica salina Ruzsky, 1905 - East Azarbayjan province, Arasbaran forest, 11 w., 15.vi.2011.

Distribution in Palaearctic: Austria, Azerbaijan, Croatia, Czech Republic, Georgia, Kazakhstan, Kyrgyzstan, Romania, Russian Federation, Slovenia.

Ponera coarctata (Latreille, 1802) - Golestan province, Minudasht, 6 w., 2 m., 9. viii.2015.

Distribution in Palaearctic: Albania, Andorra, Armenia, Austria, Balearic Islands, Belgium, Bulgaria, Channel Islands, Croatia, Czech Republic, France, Georgia, Germany, Gibraltar, Greece, Hungary, Iberian Peninsula, Israel, Italy, Kazakhstan, Kyrgyzstan, Luxembourg, Montenegro, Morocco, Netherlands, Poland, Portugal, Republic of Macedonia, Republic of Moldova, Romania, Russian Federation, Slovakia, Slovenia, Spain, Switzerland, Tunisia, Ukraine, United Kingdom of Great Britain and Northern Ireland.

Strongylognathus rehbinderi Forel, 1904 - East Azarbayjan province, Arasbaran forest, 10 w., 15.vi.2011. New record for Iran.

Distribution in Palaearctic: Armenia, Azerbaijan, Georgia, Russian Federation.

Temnothorax interruptus (Schenck, 1852) - Ardabil province, Germi, 7 w., 24.vi.2009. New record for Iran.

Distribution in Palaearctic: Armenia, Austria, Belgium, Bulgaria, Croatia, Czech Republic, Denmark, Finland, France, Germany, Hungary, Iberian Peninsula, Montenegro, Netherlands, Norway, Poland, Republic of Macedonia, Romania, Russian Federation, Slovenia, Spain, Sweden, Switzerland, Turkey, Ukraine, United Kingdom of Great Britain and Northern Ireland.

Tetramorium immigrans Santschi, 1927 - West Azarbayjan province, Maku, 6 w., 25.vii.2011. New record for Iran

Distribution in Palaearctic: Azerbaijan, Bulgaria, Turkey.

\section{Acknowledgements}

We are grateful to Dr. Barry Bolton (UK) and Dr. Brian Taylor (UK) for providing some papers. This research was supported by Islamic Azad University, and Russian Academy of Science. 


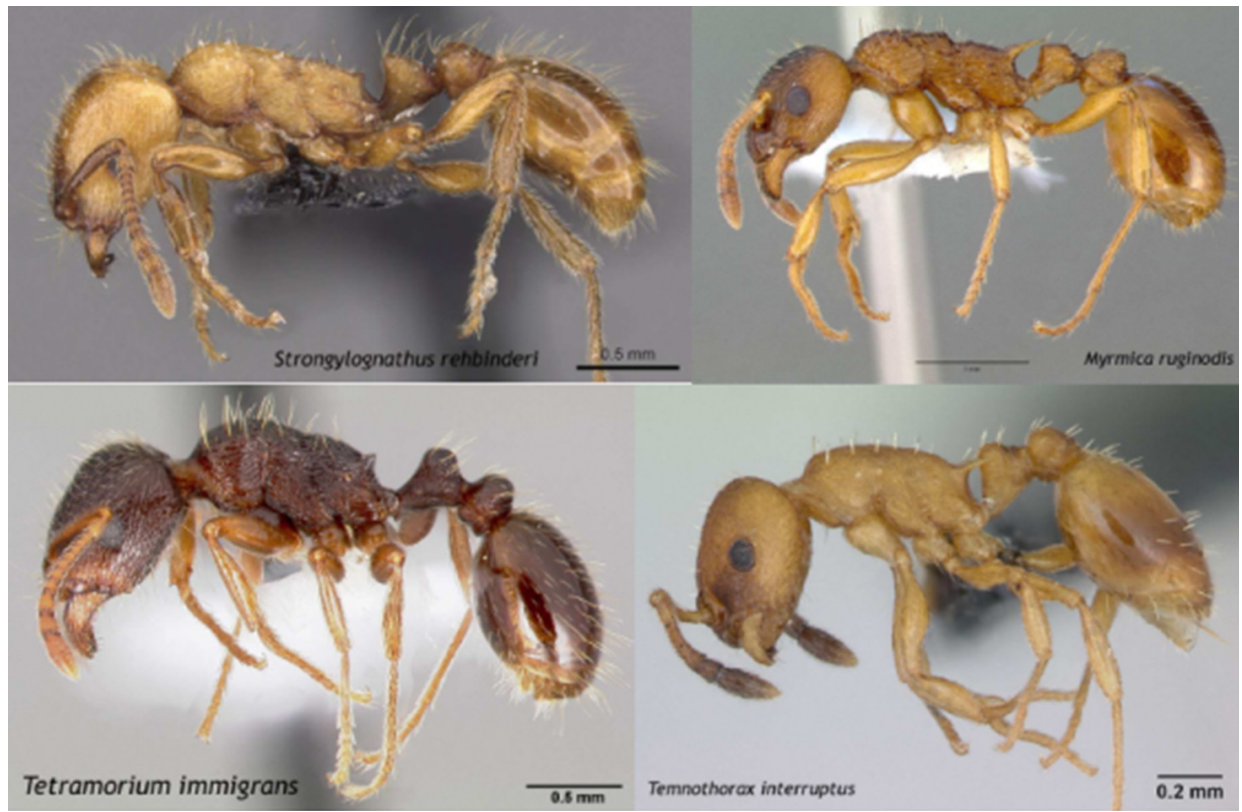

Fig. 2. Lateral view of four new records of ants from Iran (Adapted from www.antweb.org)
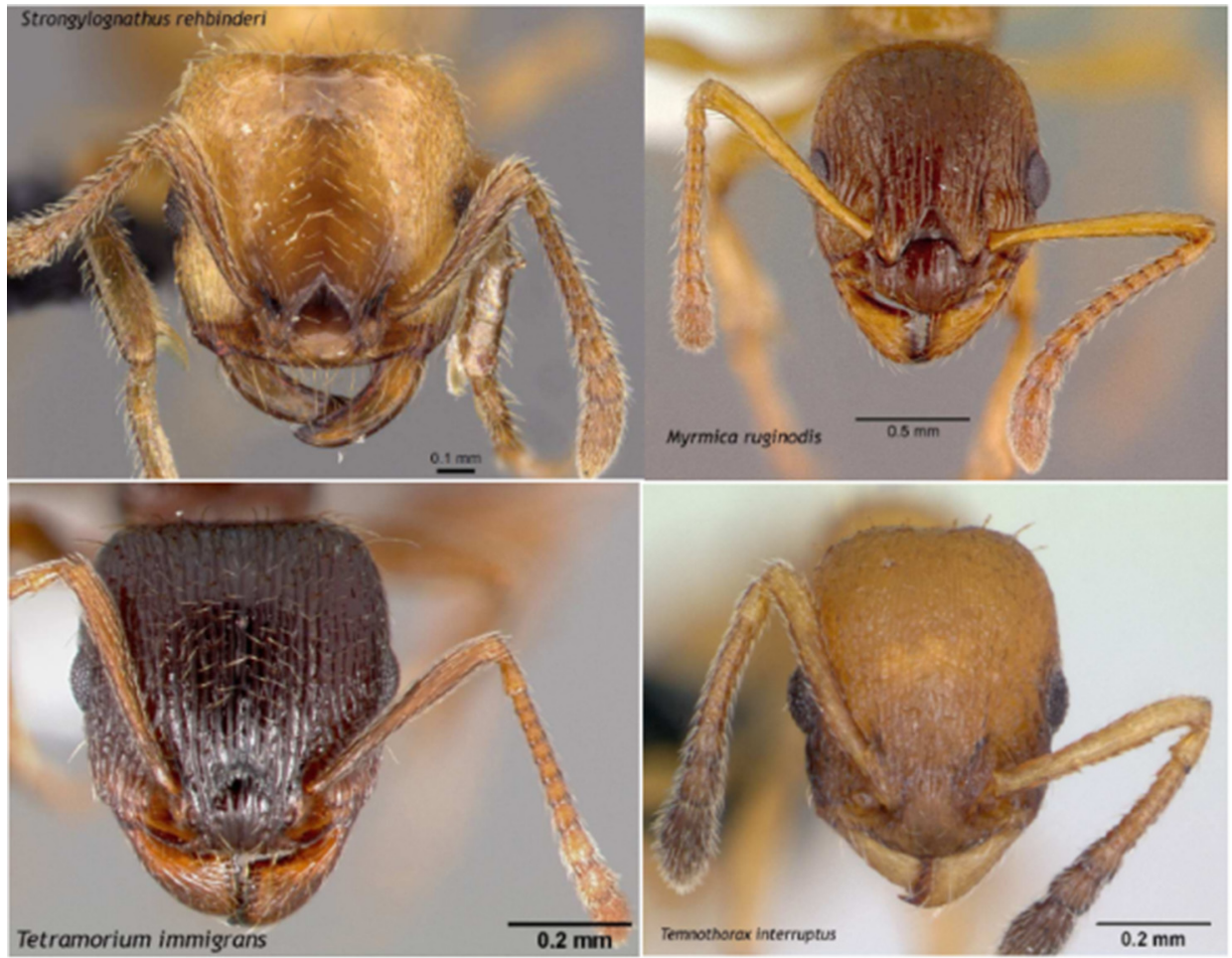

Fig. 3. Frontal view of four new records of ants from Iran (Adapted from www.antweb.org) 


\section{References}

Agosti, D., Majer, J.D., Alonso, L.E. \& Schultz, T.R. 2000: Ants: Standard methods for measuring and monitoring biodiversity. - Smithsonian Institution Press, Washington, D.C., 280 pp.

Bolton B. 2020: An online catalog of the ants of the world. Version.8.39.1. Available at: https://antcat.org. (accessed 10 June 2020).

Borowiec, L., Mossadegh, M.S., Salata, S., Mohammadi, S., Tamoli Torfi, E., Toosi, M. \& Almasi, A. 2019: Redescription of Monomorium pallidum Donisthorpe, 1918, revised status. - Asian Myrmecology 11, e011001, 2019. DOI: https://doi.org/10.20362/am.011001

Cherret, J.M. 1986: History of the leaf-cutting ant problem, pp. 10-17. In: Lofgren, C.S. \& Vander Meer R.K. (eds.), Fire ants and leaf-cutting ants: Biology and management. Westview Press, Boulder, Colorado, 435 pp. DOI: https://doi.org/10.1201/9780429038266-2

Engel, M.S. \& GRIMALDI, D.A. 2005: Primitive new ants in cretaceous amber from Myanmar, New Jersey, and Canada (Hymenoptera: Formicidae). - American Museum Novitates 3485: 1-23. DOI: https://doi. org/10.1206/0003-0082(2005)485[0001:PNAICA]2.0.CO;2

FARAHBAKHSH, G. 1961: Family Formicidae, pp. 112-113. In: Farahbakhsh, G. (ed.), A checklist of economically important insects and other enemies of plants and agricultural products in Iran. - Department of Plant Protection, Ministry of Agriculture Publication, Tehran, Iran, 133 pp.

Firouzi, F., Pashaei Rad, Sh., Hossein Nezhad, S. \& Agosti, D. 2011: Four new records of ants from Iran (Hymenoptera: Formicidae). - Zoology in the Middle East 52: 71-78. DOI: https://doi.org/10.1080/09397 140.2011.10638481

Ghahari, H., Collingwood, C.A., TABari, M. \& Ostovan, H. 2009: Faunistic notes on Formicidae (Insecta: Hymenoptera) of rice fields and surrounding grasslands of northern Iran. - Munis Entomology \& Zoology 4(1): 184-189.

Ghahari, H., Collingwood, C.A., Havaskary, M., Ostovan, H. \& Samin, N. 2011: A contribution to the knowledge of ants (Hymenoptera: Formicidae) from the Arasbaran biosphere reserve and vicinity, northwestern Iran. - Jordan Journal of Agricultural Sciences 7(3): 558-563.

Ghahari, H., Sharaf, M.R., Aldawood, A.S. \& Collingwood, C.A. 2015: A contribution to the study of the ant fauna (Hymenoptera: Formicidae) of Eastern Iran. - Beiträge Zur Entomologie = Contributions to Entomology 65(2): 341-359. DOI: https://doi.org/10.21248/contrib.entomol.65.2.341-359

Ghobadi, M., Agosti, D., Mahdavi, M., Jouri, M.H. \& MaJer, J. 2016: Ants visible from space influence soil properties and vegetation in steppe rangelands of Iran. - Sociobiology 63(4): 1063-1068. DOI: https://doi. org/10.13102/sociobiology.v63i4.1195

Grimaldi, D.A. \& ENGEL, M.S. 2005: Evolution of the insects. - Cambridge University Press, New York, 755 pp.

Heidari latibari, M., Moravvej, Gh., Zare Khormizi, M. \& Sadeghi Nameghi, H. 2017: Survey on ants (Hymenoptera: Formicidae) and their aphid partners (Homoptera: Aphididae) in northeast and center of Iran. - Entomofauna 38: 369-376.

Hölldobler, B. \& Wilson, E.O. 1990: The ants. Springer Verlag, Berlin, 732 pp.

Hossein Nezhad, S., Pashaei Rad, Sh., Firouzi, F. \& Agosti, D. 2012: New and additional records for the ant fauna from Iran (Hymenoptera: Formicidae). - Zoology in the Middle East 55: 65-74. DOI: https://doi. org/10.1080/09397140.2012.10648919

Hosseini, A., Modarres Awal M. \& Hosseini, M. 2015: New faunistic records of Formicidae (Insecta: Hymenoptera) from Iran's Northeast. - Asian Myrmecology 7: 113-127. DOI: https:/doi.org/10.20362/ am. 007011

Khalili-Moghadam, A., Borowiec, L. \& Nemati, A. 2019: New records of ants (Hymenoptera: Formicidae) from the Chaharmahal va Bakhtiari province of Iran with taxonomic comments. - Polish Journal of Entomology 88(2): 163-182. DOI: https://doi.org/10.2478/pjen-2019-0013

Khandehroo, F., Moravvej, G., Sadeghi Namghi, H. \& Fekrat, L. 2015: New records of ant species (Hymenoptera: Formicidae) to the fauna of Iran: Camponotus alii Forel, 1890 and Proformica korbi (Emery, 1909). - Asian Myrmecology 7: 129-131. DOI: https://doi.org/10.20362/am.007012

Kiran, K., Alipanah, H. \& Paknia, O. 2013: A new species of the ant genus Aphaenogaster Mayr (Hymenoptera: Formicidae) from Iran. - Asian Myrmecology 5: 45-51. DOI: https://doi.org/10.20362/ am.005006

Mohseni, M.R., Pashaei Rad, S. \& Hyati Roudbari, N. 2019: Ant species checklist in different habitats of the Central areas of Iran. - Journal of Animal Environment 11(3): 247-256. [in Persian, English Summary] 
Moradloo, S., Nafisi Fard, R., Pashaei Rad, S. \& TaYlor, B. 2015: Records of ants (Hymenoptera: Formicidae) from Northern Iran. - Zoology in the Middle East 61(2): 168-173. DOI: https://doi.org/10.10 80/09397140.2015.1020611

Modarres Awal, M. 1997: Family Formicidae, p. 274. In: Modarres Awal, M. (ed.), List of agricultural pests and their natural enemies in Iran. Second edition. - Ferdowsi University Press, 429 pp.

Modarres Awal, M. 2012: Family Formicidae, pp. 503-506. In: Modarres Awal, M. (ed.), List of agricultural pests and their natural enemies in Iran. - Third edition. Ferdowsi University Press, 759 pp.

Mirzamohammadi, S., Hosseini, M., Sadeghi, H. \& Karimi, J. 2015: Fauna of mutualistic ants associated with aphids in Golestan province. - Proceedings of the 1st Iranian International Congress of Entomology, 29-31 August, p. 74.

Mohammadi, S., Mossadegh, M.S. \& Esfandiari, M. 2012: Eight ants species (Hymenoptera: Formicidae) new for the fauna of Iran. - Munis Entomology \& Zoology 7(2): 847-851.

Moreau, C.S., Bell, C.D., Vila, R., Archibald, S.B. \& Pierce, N. 2006: Phylogeny of the ants: diversification in the age of angiosperms. - Science 312: 101-104. DOI: https://doi.org/10.1126/science.1124891

Mortazavi, Z., Sadeghi, H., Aktac, N., Depa, L. \& Fekrat, L. 2015: Ants (Hymenoptera: Formicidae) and their aphid partners (Homoptera: Aphididae) in Mashhad region, Razavi Khorasan province, with new records of aphids and ant species for Fauna of Iran. - Halteres 6: 4-12.

Paknia, O. 2006: Distribution of the introduced ponerine ant, Pachycondyla sennaarensis (Hymenoptera: Formicidae) in Iran. - Myrmecologische Nachrichten 8: 235-238.

PAKnIA, O. 2010: Diversity and species composition of ants in arid and semi-arid regions of Iran. Ph. D Dissertation, Faculty of Natural Science of the University of Ulm, $158 \mathrm{pp}$.

PaKniA, O. \& Kami, H.G. 2007: New and additional record for Formicidae (Hymenoptera: Insecta) fauna of Iran. - Zoology in the Middle East 40: 85-90. DOI: https://doi.org/10.1080/09397140.2007.10638208

Paknia, O., Radchenko, A., Alipanah, H. \& Pfeiffer, M. 2008: A preliminary checklist of the ants (Hymenoptera: Formicidae) of Iran. - Myrmecological News 11: 151-159. DOI: https://doi.org/10.15468/ req2 $\mathrm{fr}$

Paknia, O., Radchenko, A.G. \& Pfeiffer, M. 2010: New records of ants (Hymenoptera: Formicidae) from Iran. - Asian Myrmecology 3: 29-38. DOI: https://doi.org/10.20362/am.003005

Pashaei Rad, S., Taylor, B., Torabia, R., Aram, E., Abolfathi, G., Afshari, R., Borjali, F., Ghatei, M., Hediary, F., Jazini, F., Heidary Kiah, V., Mahmoudi, Z., Safariyan, F. \& Seiri, M. 2018: Further records of ants (Hymenoptera: Formicidae) from Iran. - Zoology in the Middle East 64(2): 145-159. DOI: https:// dx.doi.org/10.1080/09397140.2018.1442301

Radchenko, A.G. \& Paknia, O. 2010: Two new species of the genus Cataglyphis Foerster, 1850 (Hymenoptera: Formicidae) from Iran. - Annales Zoologici 60(1): 69-76. DOI: https://doi.org/10.3161/000345410X499533

Rafinejad, J., Zareit, A., Akbarzadeh, K., Azad, M., Biglaryan, F., Doosti, S. \& Sedaghat, M. M. 2009 : Faunestic study of ants with emphasis on the health risk of stinging ants in Qeshm Island, Iran. - Iranian Journal Arthropod-Borne Diseases 3(1): 53-59.

Salata, S., Khalili-Moghadam, A. \& Borowiec, L. 2020: Review of the Camponotus samius complex (Hymenoptera: Formicidae) in the Turano-Balkan region, with the description of a new species from Iran. - Zootaxa 4763(4): 545-562. DOI: https://doi.org/10.11646/zootaxa.4763.4.5

Shiran, E., Mossadegh, M.S. \& Esfandiari, M. 2013: Mutualistic ants (Hymenoptera: Formicidae) associated with aphids in central and southwestern parts of Iran. - Journal of Crop Protection 2(1): 1-12.

Tirgari, S. \& Paknia, O. 2004: Additional records for the Iranian fauna of Formicidae (Hymenoptera). Zoology in the Middle East 32: 115-116. DOI: https://doi.org/10.1080/09397140.2004.10638054

Werner, P. \& WIEZIK, M. 2007: Vespoidea: Formicidae (mravencovití). - Acta entomologica musei nationalis Pragae 11: 133-164.

Wilson, E.O. 2000: Foreword, pp. xv-xvi. In: Agosti, D., Majer, J.D., Alonso, L.E. \& Schultz, T.R. (eds.), Ants: Standard methods for measuring and monitoring biodiversity. - Smithsonian Institution Press, Washington, D.C., 280 pp. DOI: https://doi.org/10.5281/zenodo.11736 
